\title{
Localization and Dissemination of Soviet Marxist Philosophy in China by Zhiyuan Shen
}

\author{
Yan-hua WANG \\ Sichuan Normal University, Chengdu 610000, Sichuan, China \\ Yanhuawang2012@163.com
}

Keywords: Shen zhiyuan, Soviet marxism, Dialectical materialism, Historical materialism.

\begin{abstract}
This paper, based upon text interpretation and historical analysis methods, elaborated the Soviet philosophy in "Dialectical Materialism and Historical Materialism" translated by Zhiyuan Shen in the 1930s, and summed up the historical contribution that Zhiyuan Shen has made to the initial dissemination of Soviet Marxist Philosophy in China. This is benefit to further consummate the evolution history of Marxist Philosophy.
\end{abstract}

\section{Introduction}

Shen Zhiyuan (1902-1965), a renowned scholar born in Xiaoshan, Zhejiang Province, P.R.C., was recognized as both a Marxist philosopher and economist, and a translator and social activist. During his academic career, as a personage playing a significant role in the evolution history of the Marxist thought in China, he made outstanding achievements in and a major contribution to the localization of the Marxist Philosophy and Economics in China and applying them to study practical Chinese and international events.

Since the 1930s, Shen Zhiyuan had taught in Shanghai Jinan University, Peking University, Northwest University and other universities, and was appointed as director of the Compilation and Translation Bureau of the National Publishing General Administration of the Central People's Government, chairman of the Shanghai Committee of the China Democratic League, director of East China Military and Administrative Committee, vice chairman of the Chinese People's Political Consultative Conference Shanghai Committee, director of the Shanghai Institute of Economics of Chinese Academy of Sciences after the founding of the P.R.C.. His academic books amounted to more than 60, and his academic papers and commentaries on the current events more than 400, totaling 6 million words and covering wide-ranging subjects. He also made outstanding achievements in other fields. As the first special topic dictionary on Marxism compiled by the Chinese regarding the dissemination history of Marxism in China, A New Dictionary of Philosophy, compiled by Shen Zhiyuan in 1933, made an initial contribution to the regularization and systematization of basic vocabulary of the Marxist Philosophy. Dialectical Materialism and Historical Materialism (Volumes I \& II), compiled by Mitin Mark Borikovich and translated by Shen between 1936 and 1938, was a complete and systematic textbook on Marxist Philosophy, exerting a great influence on the Chinese ideological circles. With its Volume I republished 18 times and Volume II over 13 times, such frequent republication was rare in the Chinese publication history. And some theoretical perspectives were even adopted by Mao Zedong while composing On Practice and On Contradiction. During the years of 
probe into political economics, Shen applied his understanding of Marxism to explore the planned economics, and compiled A New Syllabus of Economics. As the earliest academic work concerning the research into the Soviet socialist planned economics, this book broke the stereotype pattern where the economic research was confined to the capitalistic economics, and pioneered the research into the socialist planned economics. In addition, during the Republic of China period, Shen also made a great theoretical contribution in popularizing Marxist Philosophy in China in the 1930s, and safeguarding and defending Marxism in the new philosophy debates. Based upon his outstanding academic achievements, Mao Zedong acclaimed Shen as a "people's philosopher" to his face in a dinner party held in the Huairen Hall (Hall of Cherishing Benevolence) in 1951.

As a renowned theorist within the Chinese ideological community, Shen Zhiyuan made a significant contribution to the localization and dissemination of the Marxist theory in China in the first half of the twentieth century. Reviewing the formation of his thought in a detailed way, it was easy to find that it intertwined with his study experience in the Soviet Union and his learning of the Soviet Marxist theory. The in-depth research into and interpretation of the Soviet Marxist theory carried out by Shen in his early years laid a solid academic and theoretical foundation for the formation of his academic thought, and for him to dedicate himself to the philosophy popularization campaign and to criticize the pseudo Marxist Ye Qing and his Trotskyite philosophy in the 1930s.

\section{Interpretation of the Soviet Marxist Philosophy}

Shen Zhiyuan, introduced by Hou Shaoqiu, joined the Communist Party of China in 1925. Dispatched by Shanghai party organization of the Communist Party of China in December 1926, Shen left for the Sun Yat-sen University in Moscow of the Soviet Union then, studied the curricula of Dialectical Materialism, Leninism, Political Economics and Chinese Revolution, and pursued his postgraduate studies in the Moscow Institute of Chinese Studies after graduation in June 1929. During his postgraduate period, Shen engaged in the compilation and translation with Chinese Publications the Compilation and Translation Section, East Department of the Communist International, and the translation and publication of the six-volume Selected Works of Lenin. And in 1931, Shen accomplished his studies and returned to China. Since then, he dedicated himself to engaging in the Party's cultural work and conducting research on social sciences, philosophy and economics. Shen Zhiyuan mainly studied and interpreted the basic theories of the Soviet Marxist Philosophy, and disseminated the latest theoretical fruits of Marxist Philosophy the Soviet philosophical circles had achieved at that time.

The Introduction of Soviet Marxist Philosophy into China started from the middle of the 1920s and reached its peak in the 1930s, since when the philosophy had become a major part of the localization of Marxism in China. Introduction of revolutionary theory intertwined with revolutionary practice, and introduction of Soviet Marxist Philosophy into China with the influence upon China of the Communist International and closer relationship between the Communist Party of China and the Soviet Union. Since China emulated the Soviet Union by following its October Revolution to save herself, China would have to follow the guideline of Soviet Marxist Philosophy [1].

At that time, two representative accomplishments Shen made while disseminating Soviet Marxist Philosophy in China comprised the Review of Soviet Philosophy 
Ideological Trends and Philosophical Sociality and Soviet Philosophy. In these papers, Shen Zhiyuan, by analyzing the relationship between philosophical evolution and socio-economic context, summarized the evolution of Soviet philosophy ideological trends before and after the October Revolution, and the social factors and historical context of its development and growth while confronting diversified opposite ideological trends of philosophy. In addition, he also introduced criticism to Mechanism and Bukharin's Metaphysics the Soviet philosophical circles conducted in the 1930s, and summarized the characteristics of basic theory of Debolin School.

Shen claimed that every philosophy comes into being along with objective requirements, resulting from peculiar socio-economic conditions. "An ideological trend of philosophy always adapts to the specific group interest of a certain social circle; and that social circle wields such philosophy ideological trend catering to his own group interest as a mighty weapon [2]." In other words, every philosophy has always been deeply ingrained with sociality and strong class features.

Affirming socioeconomic conditions as the source of philosophical evolution and analyzing social context of contradictions between diversified Soviet ideological trends of philosophy, Shen asserted, "ideological trends of philosophy transform along with socioeconomic conditions [3]; and since the early stage of primitive materialism philosophy of the ancient Greece, every ideological trend of philosophy comes into being along with objective socio-economic conditions [4]. So long as we understand the philosophical sociality and the conditions transforming philosophy ideological trends, we would grasp the nature, origin and evolution direction of Soviet Philosophy.

Elaborating the evolution of Soviet philosophy ideological trends in the Soviet socialist revolution era, Shen Zhiyuan fully affirmed the philosophical sociality and explicitly highlighted economic conditions transforming the philosophical evolution, thus seeking out the intrinsic socio-economic motivations of philosophical evolution from the ideological and cultural circles.

Based on the internal link between philosophical evolution and socio-economic conditions, Shen analyzed the social context of contradictions among diversified Soviet philosophy ideological trends in the early stage of the twentieth century, and elaborated the evolution of ideological trends for Soviet philosophy before and after the October Revolution under the peculiar historical circumstances, and analyzed historical experience of dissemination of Marxist Philosophy in the Soviet Union.

Furthermore, Shen analyzed the Soviet Mechanism and Bukharin's philosophical perspectives in a focused way. He believed that after 1926there emerged a large-scale and vigorous new ideological trend of Mechanical Materialism in the Soviet philosophical circles, the resurrection of Bogdanov's philosophy, whose philosophical perspectives could be summarized as follows:

First, putting forward a slogan of cancelling philosophy; recognizing philosophy as an anesthetic blearing human ideology; and insisting on eliminating philosophy. Second, distorting categories of material and movement; utilizing absolute physical and mechanical laws to interpret matters and movement. Third, replacing qualitative change with quantitative change and claiming the Reductionism, that is, reducing all the movement forms into a mechanical form, and all the qualitative differences into a quantitative relation. Fourth, distorting the category of unity of opposites, recognizing movement of the material as external mechanical movement. Fifth, repudiating objective existence of the contingency, and claiming all is necessary and absolute.

Criticizing the Soviet Mechanism and Bukharin's philosophy, Shen clarified the longtime confusion and chaos confronting the basic theory of Marxism and refuted 
that new Mechanism school wantonly distorted Marxism; as well as sought out the theoretical basis to criticize Ye Qing's philosophy. During the new philosophy debates launched by Ye Qing in 1936, Shen Zhiyuan put forward explicitly the localization of Trotskyite philosophy in China Ye Qing claimed had a direct relationship with the Soviet Mechanism. He pointed out Ye Qing did not initiate so-called Philosophy Elimination Perspective, but "blindly imitated" the Soviet mechanical philosophy[5].

Referring to the basic theory of Debolin School, Shen indicated that, "The so-called idealism asserted by the minority under the leadership of Debolin exposes their formalism, idealism tendency and minority feature [6]." Shen summarized the basic theory of Debolin School: first, separating theory from practice, and philosophy from politics; second, piecing out mechanically materialism to Hegelian dialectics, resulting in the Hegelianization of Dialectical Materialism; third, distorting basic laws of materialistic dialectics, especially the law of unity of opposites; fourth, ignoring Lenin's philosophy and respecting excessively Plekhanov's philosophy.

The criticism of the orthodox school for the idealism tendency of Mechanism school and Debolin School was reflected in the conflicts between the politically central school and Trotskyite's (leftist) and Bukharin's (rightist).

The preceding critical review of the Soviet Debolin philosophy was comparatively forward-looking in the academic circles in the 1930s. During the following 1950s through 1960s, China published a series of philosophy books such as Explanation for On Contradiction written by Li Dain 1951, exposing the anti-Marxism nature of Debolin school, "Dialectical Materialism and Historical Materialism" written by Ai Siqi in 1961, reviewing the universality of contradiction of Debolin school, both in tune with Shen's perspective.

\section{Basic Theory and Influence of Dialectical Materialism and Historical Materialism (Volume I)}

In the early 1930s, Shen did not only write academic papers to interpret the ideological trends of Soviet Marxist philosophy, but also translated Dialectical Materialism and Historical Materialism, "the first full and complete textbook on the new philosophy and sociology after the Soviet Purges of Soviet Philosophical Circles[7]" in the 1930s. This book was the most complete and systematic textbook introducing Marxism and Leninism in the 1930s, making a significant impact upon Chinese ideological circles.

\section{Publication and Basic Thoughts of Dialectical Materialism and Historical Materialism (Volume I)}

The original Dialectical Materialism and Historical Materialism, written by Mitin Mark Borikovich, was published in 1935. This book was a comprehensive summary of the Soviet philosophical debates from the late 1920s through the early 1930s. Shen indicated, the academic value of this book lied in that it not only reorganized the Soviet philosophy ranging from Marx and Engels to Lenin, but also established the framework of Marxist and Leninist Philosophy. He wrote, "One of its major features is that Leninist philosophy and social theory runs through this entire book from cover to cover[8]."

In view of this feature, Shen Zhiyuan set out to translate this book in 1935. Between 1936 and 1938, the two-volume Chinese version of Dialectical Materialism and Historical Materialism was published in turn. It was the most complete and systematic textbook, totaling 720,000 words in more than 1,000 pages, which 
introduces the Marxist and Leninist philosophies in China. As of 1950, this book had been republished for over eighteen times, witnessing its widespread popularity in China.

The Dialectical Materialism and Historical Materialism, comprising of 15 chapters and 88 sections, summarized the structure and system of dialectical materialism and historical materialism. In view of the great importance of Dialectical Materialism and Historical Materialism (Volume I) in the localization history of Marxism in China, its major philosophical perspectives are summarized as follows:

First, sketching the general concept of the proletarian world outlook and its essential characteristics of "unification of theory and practice"; second, narrating divergence of materialism and idealism from the fundamental question of philosophy; third, elaborating basic theory of dialectical materialism and its perspective of "Practice Comes First"; fourth, elaborating basic laws and categories of materialistic dialectics and their respective functions and effects; fifth, elaborating "two fronts" and highlighting correlation between philosophical divergence and political struggle; sixth, elaborating Lenin's contribution to dialectical materialism.

\section{Far-reaching Impacts of Dialectical Materialism and Historical Materialism}

Dialectical Materialism and Historical Materialism, translated and localized in China, made a significant impact upon Chinese ideological circles. As the most renowned of the three Soviet philosophical masterpieces [1], it made a major contribution to systematic dissemination of Dialectical Materialism and Historical Materialism in China. Selected Works of Philosophy, published under Ai Siqi's editorship in May 1939, incorporated Chapter 2 ("Materialism and Idealism") and Chapter 3 ("Dialectic Materialism"). Mao Zedong, during the revolutionary practice period in Yan'an, read through this book and added philosophical comments totaling over 2,600 words. Some theoretical perspectives and ideological materials were even adopted by Mao while composing On Practice and On Contradiction. Specifically, its far-reaching impacts could be categorized as:

First, Dialectical Materialism and Historical Materialism established the systematic textbook structure of Marxist Philosophy, whose theoretical framework has been preserved to date in China;

Second, Dialectical Materialism and Historical Materialism (Volume I) was the direct ideological origin of On Practice and On Contradiction, making a great impact upon the formation of Mao's "two-theory" philosophy. Mao Zedong extracted rich and diversified perspectives and materials and annotated with comments totaling over 2,600 words, focusing on three parts: "Social Practice: Cognitive Benchmark"; "Law of Unity of Opposites"; and "Law of Mutual Transformation of Quantitative and Qualitative Changes".

Third, Leninist philosophy and social theory run through the book of Dialectical Materialism and Historical Materialism (Volume I) from cover to cover, highlighting the contribution Leninist philosophy made to the further development of Marxist Philosophy.

Dialectical Materialism and Historical Materialism, translated and localized in China in 1938, was widely praised by progressive press circles. Monthly Reading, published in Shanghai, acclaimed this book as "the best textbook of dialectical materialism". Reading and Publishing believed that "this book elaborated the Marxism and Leninism full and complete [9]". Professor Wang Fangming published an article on the second issue of Dongyue Tribune, indicating that among the translated masterpieces of the Marxist Philosophy published before the founding of 
the P.R.C., only the Dialectical Materialism and Historical Materialism, written by Mitin Mark Borikovich and translated by Shen Zhiyuan, could be recognized as the most complete and systematic textbook introducing Philosophy of Marxism and Leninsm.

\section{Summary}

Generally, in the early 1930s, Shen Zhiyuan made a great contribution to the localization and dissemination of Soviet Marxist Philosophy in China. Except for the most complete and systematic textbook introducing Philosophy of Maxism and Leninsm and his in-depth interpretation of Soviet philosophy ideological trends as elaborated in the preceding paragraphs, Shen compiled "A New Dictionary of Philosophy", the first special topic dictionary on Marxism and Leninism, by consulting "A Dictionary of Materialistic Dialectics", compiled by Mitin Ishchenko. He also wrote "A New Syllabus of Economics", the first academic work involved in the research into the Soviet socialist planned economics by analyzing the Soviet planned economy. As one of the important disseminators, Shen made his great contribution to the localization and dissemination of Marxism in China based upon his distinct academic contributions and fruitful research results. It is necessary for us to search and review those theorists, who had made arduous explorations for the dissemination of Marxism, but had been forgotten by the history; and for us to further consummate the history of Marxist Philosophy and restore objectively the historical truth.

\section{Acknowledgement}

This work was sponsored by the Sichuan Provincial Department of Education in 2015 (WHCY1015B18).

\section{References}

[1] Suhua Xu, Dissemination, Application, Form, Prospective of Marxist Philosophy, Beijing: Beijing Press, 2002, pp.61.

[2] Zhiyuan Shen, Criticism of Modern Philosophy, Shanghai: SDX Joint Publishing Company, 1936, pp, 164.

[3][4]Zhiyuan Shen, Criticism of Modern Philosophy, Shanghai: SDX Joint Publishing Company, 1936, pp, 175-177.

[5] Zhiyuan Shen, Where Ye Qing's Philosophy is to Go?, Reading Lifestyle (II), Vol. 4, no,5. pp.5, May1936.

[6] Zhiyuan Shen, Criticism of Modern Philosophy, Shanghai: SDX Joint Publishing Company, 1936, pp, 220-226.

[7][8]Mitin Mark Borikovich, Dialectic Materialism, translated by Zhiyuan Shen, Beijing: The Commercial Press, 1936 Preface.

[9] Jiande Huang, Localization of Western Philosophy in China 1840 - 1949, Wuhan:

Wuhan Press, 1991, pp, 500. 